\title{
"The impact of real exchange rates on price competitiveness in Eastern European countries"
}

\begin{tabular}{|c|c|}
\hline AUTHORS & $\begin{array}{l}\text { Nadiia Proskurnina (D https://orcid.org/0000-0001-8587-0467 } \\
\text { R http://www.researcherid.com/rid/O-1881-2018 } \\
\text { Jürgen Kähler } \\
\text { Rosario Cervantes-Martinez (D https://orcid.org/0000-0002-1524-0379 }\end{array}$ \\
\hline ARTICLE INFO & $\begin{array}{l}\text { Nadiia Proskurnina, Jürgen Kähler and Rosario Cervantes-Martinez (2020). The } \\
\text { impact of real exchange rates on price competitiveness in Eastern European } \\
\text { countries. Economics of Development, 19(1), } 45-55 \text {. } \\
\text { doi:10.21511/ed.19(1).2020.05 }\end{array}$ \\
\hline DOI & http://dx.doi.org/10.21511/ed.19(1).2020.05 \\
\hline RELEASED ON & Friday, 05 June 2020 \\
\hline RECEIVED ON & Wednesday, 04 March 2020 \\
\hline ACCEPTED ON & Wednesday, 18 March 2020 \\
\hline LICENSE & $\begin{array}{l}(\mathrm{cc}) \mathrm{EY} \\
\text { This work is licensed under a Creative Commons Attribution } 4.0 \text { International } \\
\text { License }\end{array}$ \\
\hline JOURNAL & "Economics of Development" \\
\hline ISSN PRINT & 1683-1942 \\
\hline ISSN ONLINE & $2304-6155$ \\
\hline PUBLISHER & LLC "Consulting Publishing Company "Business Perspectives" \\
\hline FOUNDER & Simon Kuznets Kharkiv National University of Economics \\
\hline
\end{tabular}

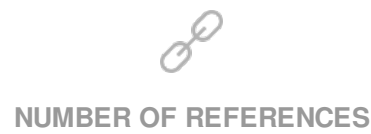

36

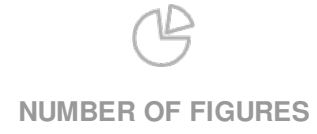

6

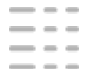

NUMBER OF TABLES

3

(C) The author(s) 2021. This publication is an open access article. 


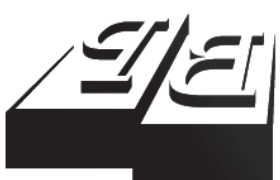

BUSINESS PERSPECTIVES

Publisher

LLC "CPC "Business Perspectives" Hryhorii Skovoroda lane, 10, Sumy, 40022, Ukraine www.businessperspectives.org

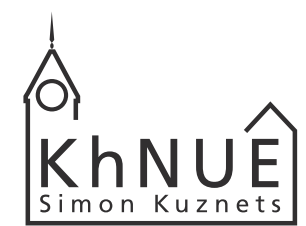

\section{S. KUZNETS KHNUE}

Founder

Simon Kuznets Kharkiv National University of Economics, Nauky avenue, 9-A, Kharkiv, 61166,

Ukraine

http://www.hneu.edu.ua/

Received on: 4th of March, 2020 Accepted on: 18th of March, 2020 Published on: 05th of June, 2020

๑) Nadiia Proskurnina,

Jürgen Kähler,

Rosario Cervantes-Martinez, 2020

Nadiia Proskurnina, Ph.D. in Economics, Associate Professor, Head of the Department of International Economics and Management of Foreign Economic Activity, Simon Kuznets Kharkiv National University of Economics, Ukraine.

Jürgen Kähler, Ph.D., Professor, Department of Economic Sciences, Friedrich-Alexander-Universität Erlangen-Nürnberg, Germany.

Rosario Cervantes-Martinez, Ph.D., Professor, Universidad de Guadalajara, Mexico.

\section{(ㄷ) (i)}

This is an Open Access article, distributed under the terms of the Creative Commons Attribution 4.0 International license, which permits unrestricted re-use, distribution, and reproduction in any medium, provided the original work is properly cited.

Nadiia Proskurnina (Ukraine), Jürgen Kähler (Germany),

Rosario Cervantes-Martínez (Mexico)

\title{
THE IMPACT OF REAL EXCHANGE RATES ON PRICE COMPETITIVENESS IN EASTERN EUROPEAN COUNTRIES
}

\begin{abstract}
The subject of this paper is empirical research on studies of exchange rates in Eastern European countries, such as Albania, Bulgaria, Bosnia and Herzegovina, Belarus, Czech Republic, Estonia, Croatia, Hungary, Latvia, Lithuania, Moldova, (North) Macedonia, Montenegro, Poland, Romania, Serbia, Slovakia, and Slovenia, in order verify the validity of theories that explain these changes. This research aims to explain the mixed evidence of the Balassa-Samuelson effect in Ukraine, taking into account the intentions of Ukraine to become a member of the European Union. Unlike previous works, the attention is shifted to a review of empirical evidence and the identification of main factors that limit the ability to verify the theory. The main conclusion is that all the currencies studied underwent substantial real appreciations during the study period. Thus, it can be concluded that an adequate monetary policy in countries under study is very important, given that local exchange markets are not sustainable enough and the volatility of exchange operations is higher than in countries with developed economies. However, the Balassa-Samuelson Hypothesis (BSH) can explain the impact of the real exchange rate due to changes in productivity in countries in transition.
\end{abstract}

Keywords

JEL Classification purchasing power parity, real exchange rate, the Balassa-Samuelson effect, real effective exchange rate, changes in productivity

B27, C33, C58, E5, F36, F4

Н. В. Проскуріна (Україна), Юрген Келер (Німеччина), Росаріо Сервантес-Мартінес (Мексика)

\section{ВПЛИВ РЕАЛЬНИХ ОБМІННИХ КУРСІВ НА ЦІНОВУ КОНКУРЕНТОСПРОМОЖНІСТЬ КРАЇН СХІДНОÏ ЄВРОПИ}

\begin{abstract}
Анотація
Предметом даної статті $є$ емпіричне дослідження щодо вивчення валютних курсів валют у країнах Східної Європи, таких як Албанія, Болгарія, Боснія та Герцеговина, Білорусь, Чехія, Естонія, Хорватія, Угорщина, Латвія, Литва, Молдова, (Північ) Македонія, Чорногорія, Польща, Румунія, Сербія, Словаччина, Словенія з метою перевірити обгрунтованість теорій, що пояснюють ці зміни. Це дослідження має на меті пояснити неоднозначні докази БалассаСамуельсона також і в Україні, враховуючи стійке прагнення нашої країни стати членом Європейського Союзу. На відміну від існуючих досліджень, в статті увагу зосереджено на наявності емпіричних доказів та визначенні основних факторів, які підтверджують або обмежують можливість перевірки теорії. Основний висновок полягає в тому, що всі валюти країн, що досліджувались, були значною мірою переоцінені протягом періоду дослідження. Також, можна зробити висновок, що адекватна грошово-кредитна політика в країнах, що вивчаються, $\epsilon$ дуже важливою, враховуючи, що місцеві валютні ринки недостатньо стійкі, а волатильність валютних операцій вище, ніж у країнах з розвиненою економікою. Однак, гіпотеза Баласа-Самуельсона підтвердила свою здатність пояснити вплив реального обмінного курсу за рахунок зміни продуктивності реальних секторах економіки під час перехідного періоду.
\end{abstract}

Ключові слова

Класифікація JEL паритет купівельної спроможності (РРP), реальний обмінний курс, ефект Баласса-Самуельсона, реальний ефективний змінний курс, зміна продуктивності B27, C33, C58, E5, F36, F4 


\section{INTRODUCTION}

One of the tasks for a new country is to have higher productivity growth than an average rate growth in EU, and the rate of inflation should achieve the level where the prices are stable. Also, it is important to support an optimal inflation rate. However, due to the fact that the majority of countries joining the European Union has undergone or are still in the process of transition, this task is difficult. The vital role plays an exchange rate, which links the real and nominal sides of the convergence according to Maastricht criteria.

To apply the exchange rate regime that is most suitable for the current economic situation, a theoretical background is needed. If the theory has been tested and proven, it can help a country to strengthen the economy, but also improve the trading relations.

The idea of changes in real exchange rate via the improvement in relative productivity between traded and non/ traded sector of the economy has been offered by Balassa (1964) and Samuelson (1964). The hypothesis of researchers has found a lot of empirical evidences decades ago. However, the estimates were not supported by high-quality data and poor econometric tools. After half of the century the theory has developed and nowadays it can be applied not only for domestic but also for international comparison. The Balassa-Samuelson hypothesis has been used recently tested by the majority of European countries in transition due to the desire to fulfil Maastricht criteria of the European Monetary Union. EU membership imposes certain rules controlling the real exchange rate and inflation in the economy of a potential member. During the literature review on the empirical evidences of the Balassa-Samuelson Hypothesis in European countries, there are always specific factors that affect the evaluation.

Literature review. One of the most used empirical tools for analyzing the degree of misalignment of a real exchange rate (RER) is the Purchasing Power Parity (PPP). It has got brief attention after the 90 s due to the availability of a wider range of datasets and new econometrical tools. Even if the theory still counted as poorly tested and it is not always confirmed by practical evidences, the PPP theory plays an important role for various international organizations, including the World Bank and European Union (European Union).

The theory was articulated by Cassel (1918). Originally it is based on the law of a single price which claims, that after conversion of currencies between two trading countries, their national prices on a common basket good will be equalized. The first studies applied a theory via testing such currencies as the pound sterling, the French franc, and the US dollar over a period of more than one hundred years. The enlargement of researches on the PPP, economists suggested that it is a useful tool which can be implemented in the long run for understanding the behaviour of currency exchange rates (Chinn, 2006). Based on this statement, it can be assumed that if various types of costs and benefits (such as transport and information) are symmetrical for two trading countries, then in the short-term concept of PPP will not hold. According to Cassel's (1918) theory, the deviations between exchange rates and PPP are counted as a minor issue. The applicability of the theory was presented in findings during the Gold Standard period, time intervals between wars, and through timelines of the validity of systems with fixed exchange rates. The theory did not have significant empirical results during the time of changing fixed currency rates to a floating regime.

After the cancellation of the Bretton Woods agreement, economists have got controversial results regarding PPP, which is called Power Purchasing Parity Puzzle (Rogoff, 1996). The PPP puzzle has two main arguments. The first one is the availability to hold PPP in a long period. The solution of this issue has been introduced in works of Taylor (2002) and Sarno (2002). They explained the presence of such an effect using non-linearities in exchange rates. However, the second part of the puzzle stated on stationary behaviour of half-lives of deviations from PPP (Froot and Rogoff, 1994; Giovannini, 1998; Halpern and Wyplosz, 2001; Isard, 1977). In empirical studies, the aggregation of time in data has been stated as a major cause of the bias. Indeed, one of the researches showed that half-life deviations can be minimized to two and a half years (Flood and Taylor, 1996).

The imperfection of the model was also mentioned due to the absence of many goods in a common good basket, which cannot be internationally traded due to limitations of trade barriers. Under these settings, the theory misses the link between the prices of a large group of goods and exchange rates (Rogoff, 1996). 
Furthermore, the majority of studies of the model's imperfection identified more reasons for the disproportion in PPP. An exchange rate movement (Isard, 1977), trade barriers (Parsley and Wie, 1996), pricing to the market (Dornbusch, 1987), transport costs and tariffs (Sarno and Chowdhury, 2001; Sarno and Taylor, 2002), monetary and currency shocks (Clarida and Gali, 1994) were taken as major factors that affect the disproportion between real exchange rates.

The question of currency shock effect has got a lot of attention, especially during the time of evaluation PPP theory separately for countries with high-, middle- and low- income. For more developed countries half-time was stated from 4 to 5 years. That means that such type of effects on RER will decrease by approximately 15\% each year. This fact just strengthens the power of other factors on changes in exchange rates (O'Connell and Wie, 1997). On the other hand, it was argued that they can cause short-term effects, for example as a monetary policy (Dornbusch, 1987). The theories providing the background reasoning of deviations in the model were needed. One of the alternative theories which explain the nature of deviations in PPP is called the Balassa-Samuelson Hypothesis (BSH).

The theory was built in seminal papers of Balassa (1964) and Samuelson (1964). However, the hypothesis can be also called Harrod-Balassa-Samuelson, Ricardo- Harrod-Balassa-Samuelson-Penn, due to their scientific contribution to the theory independently from each other (Taylor, 2002). In this paper, terms such as the BalassaSamuelson (BS) effect, hypothesis and model will be used.

In the first work of Balassa and Samuelson was found the positive correlation between price levels and GDP per capita. Such dependence explained the reason for an unjustifiable appreciation of currencies in high-income countries. Later it was argued that if unequal international levels of labor productivity will be higher in exported production of goods than in the production of non-exported goods, the national currency of the country with rapid growth will have relatively higher prices. As a result, the connection between the ratio of PPP and exchange rates is a growing income function (Balassa, 1964; Samuelson, 1964).

The model was not formulated in the early works of Balassa and Samuelson. The starting point was an assumption regarding the dependence of prices and productivity, which was proved by empirical results. The main idea of the original BS theory is that the relative change of productivity in sectors dependent on the tradability of goods will cause changes in the comparative prices.

Further, the theory has got a mathematical formulation. The BS model assumes that a country has two sectors of traded and non-traded goods. The function of capital and labor with different sectoral productivity accumulate an output. Labor in the model is counted mobile and fully used (Blaszkiewicz, Kowalski, Rawdanowicz and Wozniak, 2004).

The basic model assumes the free factors of production:

$$
\begin{aligned}
& Y_{T}=A_{T} K_{T} L_{T}^{1-\alpha}, \\
& Y_{N}=A_{N} K_{N} L_{N}^{1-\beta},
\end{aligned}
$$

where the total output (a sum of $Y_{T}$ and $Y_{N}$ ) is a constant value to scale Cobb-Douglass function of three inputs A (productivity), $\mathrm{K}$ (capital) and L (labour) for two sectors of traded ( $\mathrm{T}$ ) and non-traded goods (N) (Blaszkiewicz, Kowalski, Rawdanowicz and Wozniak, 2004).

Under the assumption of perfect competition and capital mobility, the rental rate of capital (R) and the wage gives (W):

$$
\begin{aligned}
& R=\left(1-\alpha_{T}\right) \cdot A_{T} \cdot\left(\frac{K_{T}}{L_{T}}\right)^{-\alpha_{T}}=P \cdot\left(1-\alpha_{N}\right) \cdot A_{N} \cdot\left(\frac{K_{N}}{L_{N}}\right)^{-\alpha_{N}} . \\
& W=\left(\alpha_{T}\right) \cdot A_{T} \cdot\left(\frac{K_{T}}{L_{T}}\right)^{1-\alpha_{T}}=P \cdot\left(\alpha_{N}\right) \cdot A_{N} \cdot\left(\frac{K_{N}}{L_{N}}\right)^{1-\alpha_{N}} .
\end{aligned}
$$


Log-differentiating of $\mathrm{R}$ and $\mathrm{W}$ will give a result:

$$
\Delta P=\left(\frac{\alpha_{T}}{\alpha_{N}}\right) \cdot \Delta A_{T}-\Delta A_{N}
$$

The model includes two missing points of PPP theory:

1. Changes in labor productivity and real incomes due to technological progress effects fluctuation between exchange rates.

2. The sector of non-tradable goods (including services) is a part of a deviation result in PPP theory.

Nevertheless, even due to the new view on the behaviour of real exchange rates, the model had its' imperfections. First of all, there was no explanation regarding the demand side of tradable and non-tradable goods. Asea and Mandoza (1994) and Gregorio, Giovannini and Wolf (1994) have incorporated the model including governmental expenditure as the factor of shifting demand between goods. From their findings, the demand can cause changes in relative prices.

The first time the relationship between relative exchange rates and productivity differentials was tested in a work of Hsieh (1982) on examples of Japan, Germany and their major trading partners. However, the BS model, which is used until nowadays was presented later in the 90s by Marston (1987). The author included the evaluation of the relationship between relative productivity, exchange rates and relative prices. He used a dataset from the Economic Cooperation and Development Organization and built a model of real yen to the USA dollar exchange rate for a 10-year period. In empirical evidences the long-term appreciation of the yen against the dollar was explained via the existence of productive differentials between tradable and non-tradable goods.

Contradicting the previous works regarding the estimation of the BSH in Central and Eastern Europe by Mihaljek and Klau (2004), Egert (2002a, 2002b, 2003, 2004, 2005) and Candelon and Kool (2007). It is necessary to emphasize that works of Mihaljek and Klau and also Egert have got different results.

Table 1. Review of Egert's studies on the Balassa-Samuelson Hypothesis in selected European countries

\begin{tabular}{|c|c|c|c|}
\hline Author & Period & Countries & Existence of the BS effect \\
\hline Egert (2002) & $1991-2001$ & $\begin{array}{l}\text { Czech Republic, Hungary, Poland, } \\
\text { Slovenia, Slovakia }\end{array}$ & $\begin{array}{l}\text { Appreciation was explained for half of the countries } \\
\text { (especially in Poland with } 3 \% \text { ) }\end{array}$ \\
\hline Egert et.al. (2003) & $1995-2000$ & $\begin{array}{l}\text { Czech Republic, Hungary, Poland, } \\
\text { Slovenia, Slovakia + Croatia, Estonia, } \\
\text { Latvia, Lithuania }\end{array}$ & No effect \\
\hline Egert (2005) & $1991-2004$ & $\begin{array}{l}\text { Bulgaria, Croatia, Romania, Russia, } \\
\text { Turkey, Ukraine }\end{array}$ & $\begin{array}{l}\text { The BS effect exists, but its' contribution does not } \\
\text { play major role in RER changes }\end{array}$ \\
\hline
\end{tabular}

From Table 1 the existence of the BS effect can be doubtful for Central and Eastern European countries. However, the author in his latest work stated on the importance to take into consideration country-specific factors, which can affect the overall result of the estimation. For example, in the 2005's work the RER behaviour was tested on the existence of Dutch disease (Egert, 2005). Even if at the end the result was not the same as predicted.

The finding on study cases based on one country had also controversial results. For example, the study case of Romania (Table 2).

The findings during the domestic evaluation of the BS effect showed that the estimation result can vary dependently on the used type of model, the classic or extended one (Dumitru and Ionela, 2009). 
Table 2. Review of studies on the Balassa-Samuelson Hypothesis in Romania

\begin{tabular}{l|r:l:l}
\hline \multicolumn{1}{c}{ Author } & Period & Type of study & \multicolumn{1}{c}{ Existence of the BS effect } \\
\hline Halpern and Wyplosz (2001) & $1991-1998$ & International & $3 \%$ is an average annual appreciation explained by BSH \\
Arratibel et.al (2002) & $1990-2001$ & International & No significant effect \\
Egert (2005) & $1991-2004$ & International & The effect is poorly determined \\
Dumitru (2008) & $1998-2006$ & Domestic & The effect can be estimated from $0.24 \%$ to $5.06 \%$ \\
Dumitru and lonela (2009) & $1998-2006$ & Domestic & The effect can be estimated from $0.6 \%$ to $2.46 \%$ \\
Dedu and Dumitrescu (2010) & $2002-2006$ & Domestic & Low estimation results \\
\hline
\end{tabular}

The BSH can be applied for one economy, as well as for a comparison of RER between two or several countries.

Methods of research. An important econometric issue in testing for PPP is the fact that price levels and nominal exchange rates are typically non-stationary variables. To avoid spurious correlation, PPP is tested with cointegration analysis or in the form of relative PPP.

When a summary measure of price competitiveness vis-à-vis the main trading partners is required, a weighted average of real exchange rates, i.e. a real effective exchange rate $\left(R E E R_{t}\right)$, is computed. This leads to several issues of index construction like the choice of weights, of prices or price indices and of countries, for an overview see Chinn (2006). As regards weights, the most popular method is to use double weights that take into account direct trade flows and also third-market effects. Because of data availability, the most popular choice of a price index is the consumer price index (CPI) but also indices of labor unit costs, whole-sale prices or GDP deflators are used. For consistency, the nominal exchange is converted to an index with the same base period and base-period value, typically 100, as the price indices. Alternatively, absolute prices can be applied instead of price indices.

There are two important implications of using price indices instead of absolute prices. First, in testing for PPP with price indices, there is the implicit assumption that PPP holds in the base period. Secondly, the value of a real exchange rate at a time can only be interpreted as the cumulative relative change with respect to the base period. A value larger (smaller) than the base value cannot be interpreted as overvaluation (undervaluation). When the analysis is conducted with price indices, it would be more appropriate to refer to cumulative relative PPP instead of absolute PPP and the terminology absolute PPP should be reserved for studies where absolute prices are used. In the first case, the price index answers the question: How much more or less does the basket of goods and services cost at a time than in the base period? In the second case, the question is: How much does this basket cost in the currency of the country? Authors refer to the first real exchange rate as based on cumulative relative effects $\left(Q_{t}^{C R}\right.$ and $R E E R_{t}^{C R}$ for real effective exchange rates) and the second real exchange rates are based on price levels ( $Q_{t}^{P L}$

and $\left.R E E R_{t}^{P L}\right)$. The extent of cumulative appreciation or depreciation with respect to the base period is measured by $Q_{t}^{C R}$ or $R E E R_{t}^{C R}$ whereas $Q_{t}^{P L}$ and $R E E R_{t}^{P L}$ measures the extent of over- or undervaluation (Chinn, 2006).

The aim of this paper is to reveal the impact of the real exchange rates politics on price competitiveness in east European countries analyzing trends in relative productivity changes of traded vis-à-vis non-traded sector.

\section{RESULTS}

Since the geographical notion of East Europe is not uniquely defined, it is acceptable to define the sample countries as those European countries on the territory of the former COMECON, including the associate member Yugoslavia, but without Russia. This includes the following 19 countries: Albania, Bulgaria, Bosnia \& Herzegovina, Belarus, Czech Republic, Estonia, Croatia, Hungary, Latvia, Lithuania, Moldova, (North) Macedonia, Montenegro, Poland, Romania, Serbia, Slovakia, Slovenia and Ukraine. The $R E E R_{t}^{C R}$ shown in Figures 1-3 are based on CPI. Data sources are IMF and Eurostat.

Figure 1 shows the time series of $R E E R_{t}^{C R}$ for Eastern European EU-members that introduced the euro. The first country to do so was Slovenia in 2007, followed by Slovakia in 2009, Estonia in 2011, Latvia in 2014 and Lithuania in 2015. It is apparent that, except Slovenia (turquoise line), all countries underwent substantial real appreciations of their currencies in the period of transition, as predicted by the Balassa-Samuelson effect. The appreciation was 


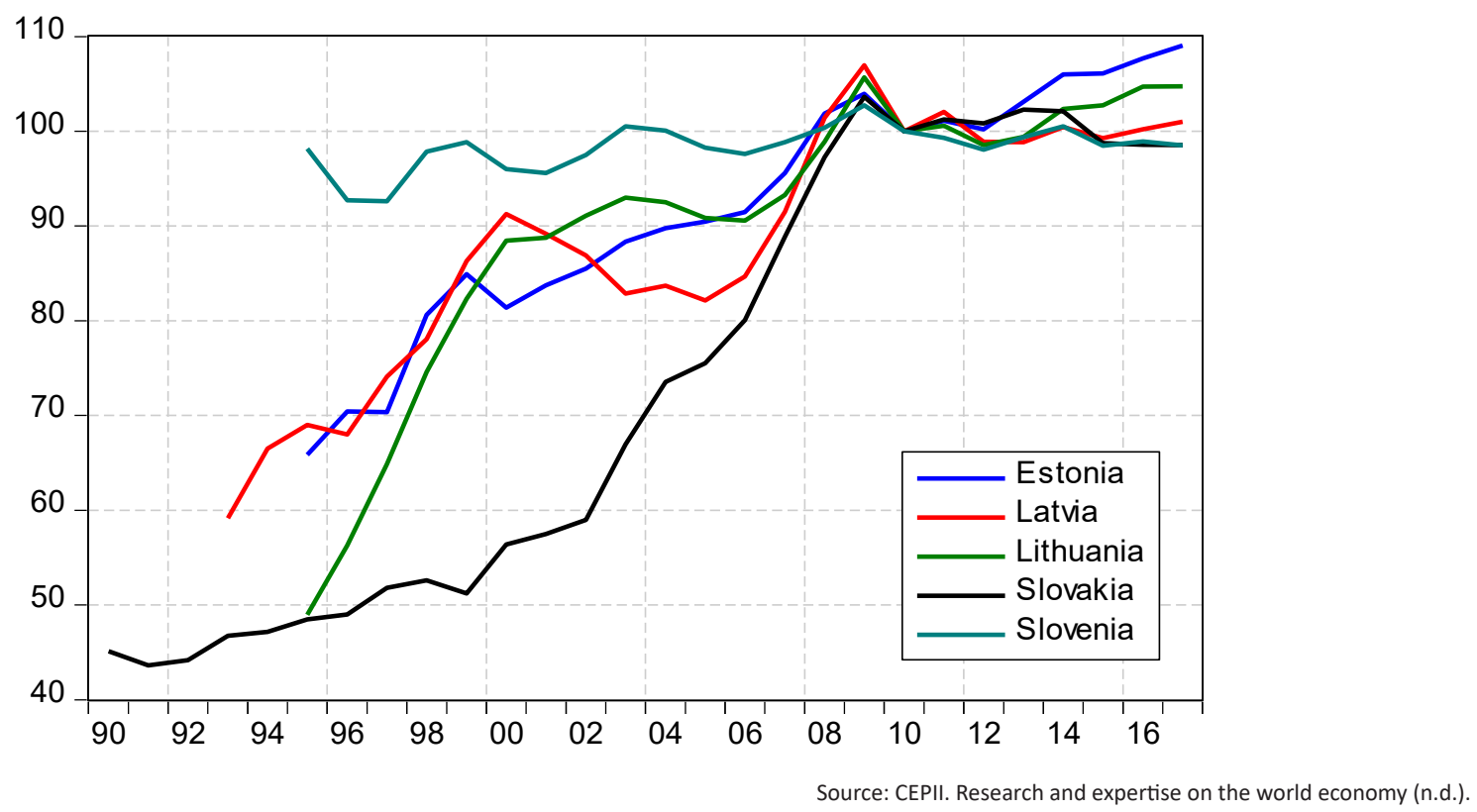

Figure 1. $R E E R_{t}^{C R}$ for countries that introduced the euro

especially strong for Slovakia (black line) and Lithuania (green line). The most remarkable fact is that for these five countries, the real appreciation came more or less to an end by 2009 or 2010, just after the International Financial Crisis and the Great Recession although Estonia (blue line) has seen a continuation of appreciation in recent years.

The time series of $R E E R_{t}^{C R}$ for the six Eastern European EU-members that have not introduced the euro yet in Figure 2 are not much different from the paths that the euro-countries show in Figure 1. Again by 2009 or 2010, the convergence in terms of $R E E R_{t}^{C R}$ was to a large extent complete. Bulgaria (blue line), the Czech Republic (green line) and Romania (purple line) are the countries that witnessed the largest appreciations of their currencies. The country with the smallest volatility in its $R E E R_{t}^{C R}$ is Croatia (red line). Some countries experienced real depreciation after 2010, especially Hungary (black line).

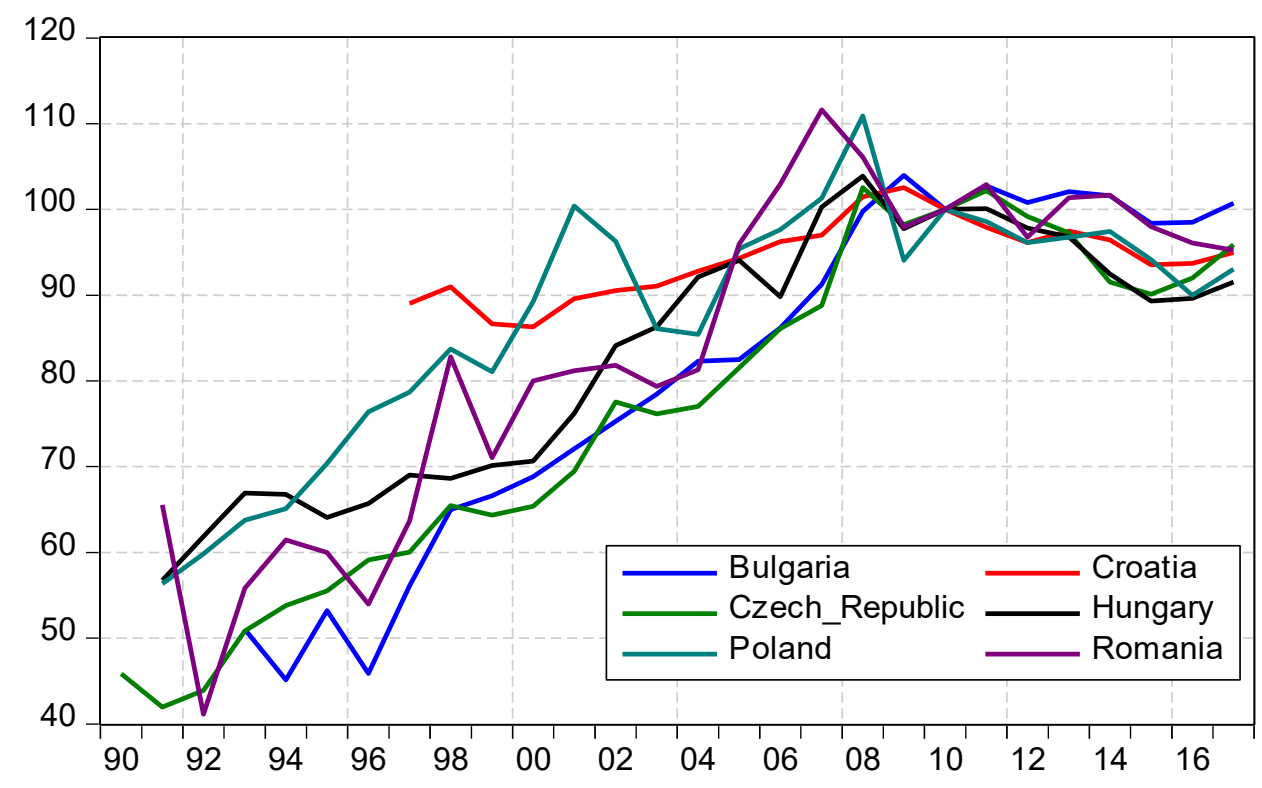

Source: CEPII. Research and expertise on the world economy (n.d.).

Figure 2. $R E E R_{t}^{C R}$ for EU countries with non-euro currencies 
Figure 3 shows for three non-EU countries the development of their. The contrast to the other two groups of countries is quite remarkable, especially for Macedonia (blue line) and Ukraine (green line). Both countries experienced in the transition period a real depreciation of their currencies instead of a real appreciation. There was very high volatility of Ukraine's $R E E R_{t}^{C R}$ in the mid-1990s that might be related to the hyperinflation period of the karbovanets. The further real depreciation of the hryvnia after 2013 is certainly linked to political and military events in Ukraine.

Like the tongue-in-cheek Big-Mac Standard, the $Q_{t}^{P L}$ can answer the question of whether a currency is undervalued or valued. As explained above, absolute PPP holds when $Q_{t}^{P L}=1.0$. Alan Heston, Irving Kravis and Robert Summers from the University of Pennsylvania conducted an international project to collect and compare individual price around the globe and published the results in the Penn World Tables (PWT). When aggregated to a country's price level of a basket of goods and services, this can be used to create a real exchange rate $Q_{t}^{P L}$.

Meanwhile compiled at the University of California, Davis and the University of Groningen, the PWT report different price levels for different baskets of goods and services. Here the current prices of output-side GDP had been used. The USA is the reference country, for an overview of the PWT see Feenstra et al. (2015). Other than in a $Q_{t}^{C R}$, in a $Q_{t}^{P L}$ prices are not summarized in a price index that is referenced to a base period but is expressed as the local currency cost of a basket of goods and services.

Figure 4 shows for the set of five East European countries that have introduced the euro, the real exchange rates $Q_{t}^{P L}$ against the US dollar. Although there are substantial methodical differences between the $R E E R_{t}^{C R}$ in Figure 1 and the $Q_{t}^{P L}$, the paths of the real exchange rates are quite similar. All countries experienced strong real appreciations against the dollar until 2008 which was followed by more or less continuous real depreciations. Slovenia is the only country that reached parity with the price level of the USA in 2008, one year after the introduction of the euro. Figure 4 shows that the Baltic countries and Slovakia still enjoy quite substantial price advantages vis-à-vis the USA as a benchmark.

Figure 5 displays $Q_{t}^{P L}$ for the same set of countries like in Figure 2 and both graphs show remarkably similar patterns. There were strong real appreciations of local currencies against the US dollar until 2008 and followed by a tendency of real depreciations thereafter. The most important additional information that can be derived from Figure 5 is that all countries have not exhausted their price advantage against the USA yet. This is especially true

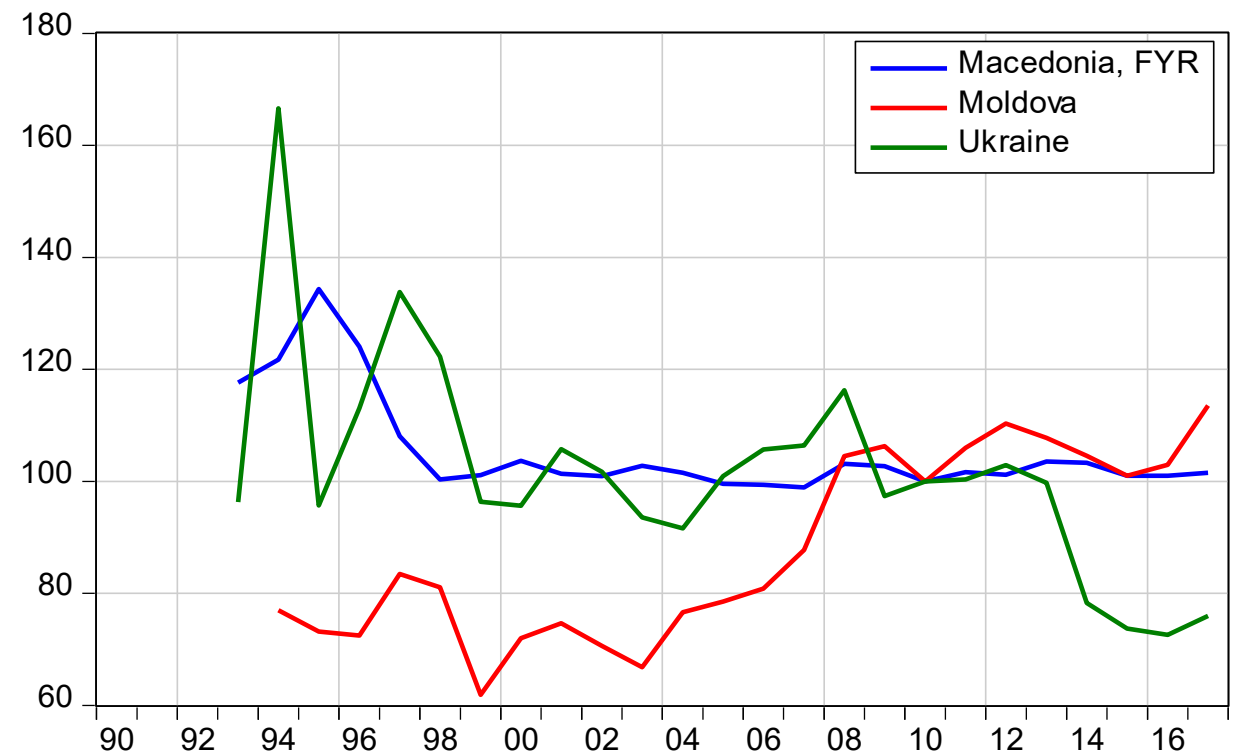

Figure 3. $R E E R_{t}^{C R}$ for non-EU countries 


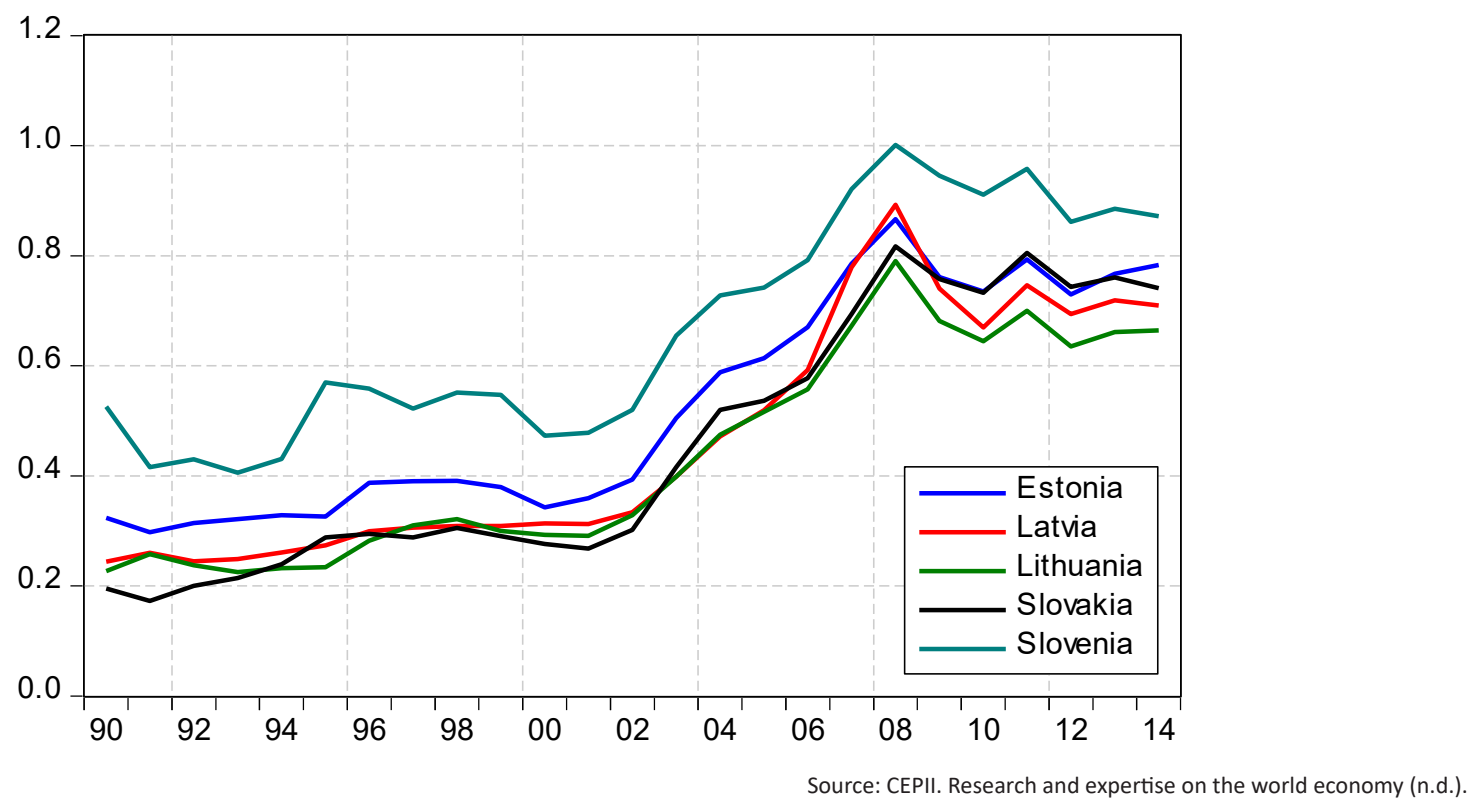

Figure 4. $Q_{t}^{P L}$ for countries that introduced the euro

for Bulgaria (blue line). In 1990 Bulgaria's price level was a fifth of the US price level. After a period of strong real appreciation of the lev that continued until 2008, Bulgaria's price level has maintained a rather stationary ratio of between 0.4 and 0.5 to the US price level, i.e. the price advantage of Bulgaria vis-à-vis the USA is still large.

The puzzling result of Figure 3 was that Macedonia and Ukraine did not show any prolonged periods of real appreciation according to their $R E E R_{t}^{C R}$. The story is completely different in Figure 6 which displays the $Q_{t}^{P L}$ series instead. The Ukrainian price level increased from 15.4\% of the US price level in 2000 to 41.4 percent in 2008 and the Macedonian price level rose from 22.7\% of the benchmark in 2001 to $45.0 \%$ in 2008. Most importantly, all the countries maintained a very substantial price advantage against the benchmark throughout the sample period. In 2014 their price levels were still less half the price level of the USA. The strong real depreciation of the hryvna against the dollar in 2014 reduced the Ukrainian price level to less than a third of the US price level.

It is also acceptable testing for the Penn effect using the $Q_{t}^{P L}$ series, i.e. that the value of the real exchange rate is an increasing function of the level of development as measured by GDP per capita. In terms of the Big Mac standard, the Penn effect implies that, when expressed in the same currency, Big Macs are cheaper in developing countries than in highly developed countries. The models had been drawn on the most recent PWT 9.0 that includes data for 182 countries starting in 1950. For most East European countries, the data start in 1990 and for some (Albania, Bulgaria, Hungary Poland and Romania) a few decades earlier. Based on this panel dataset the hypothesis that in the simple linear regression model had been tested:

$Q_{i t}^{P L}=\beta_{1}+\beta_{2} \frac{G D P_{i t}}{\text { Population }_{i t}}+\varepsilon_{i t}$

the slope coefficient $\beta_{2}$ is zero. In some variants of the model, fixed effects (FE) or random effects RE) are added to the right-hand side of (6).

Table 3 reports in the upper panel the results for the whole sample of 182 countries with a maximum number of 9.439 observations (year-countries) from the database CEPII. For all three model variants, the slope coefficient is positive. Although the adjusted $R^{2}$ is rather small, the slope coefficient is highly significant. All $t$-values are extremely large. The Schwarz Information Criterion (SIC) seems to suggest that the pooled model should be preferred to the FE model but direct testing of the FE model against both the pooled model (with an F test) and the RE model (with the Hausman test), shows that indeed the FE model is the best model. 


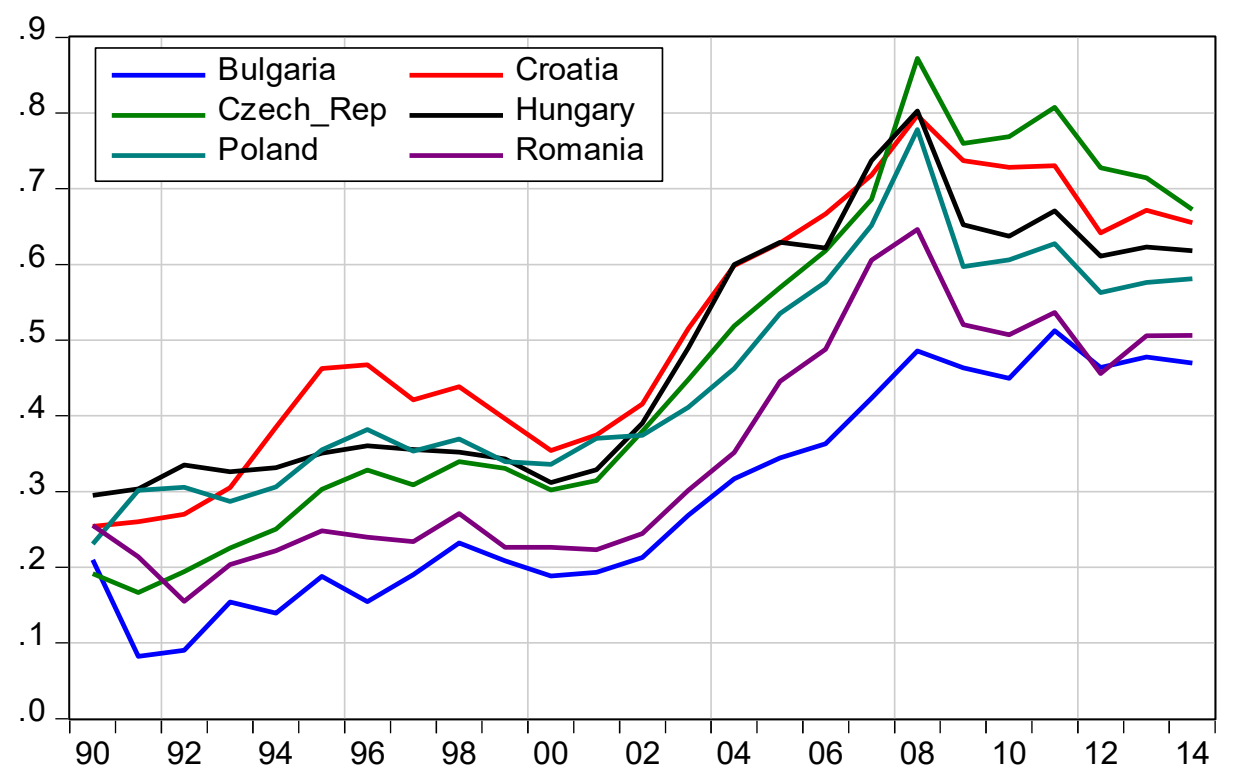

Source: CEPII. Research and expertise on the world economy (n.d.).

Figure 5. $Q_{t}^{P L}$ for EU countries with non-euro currencies

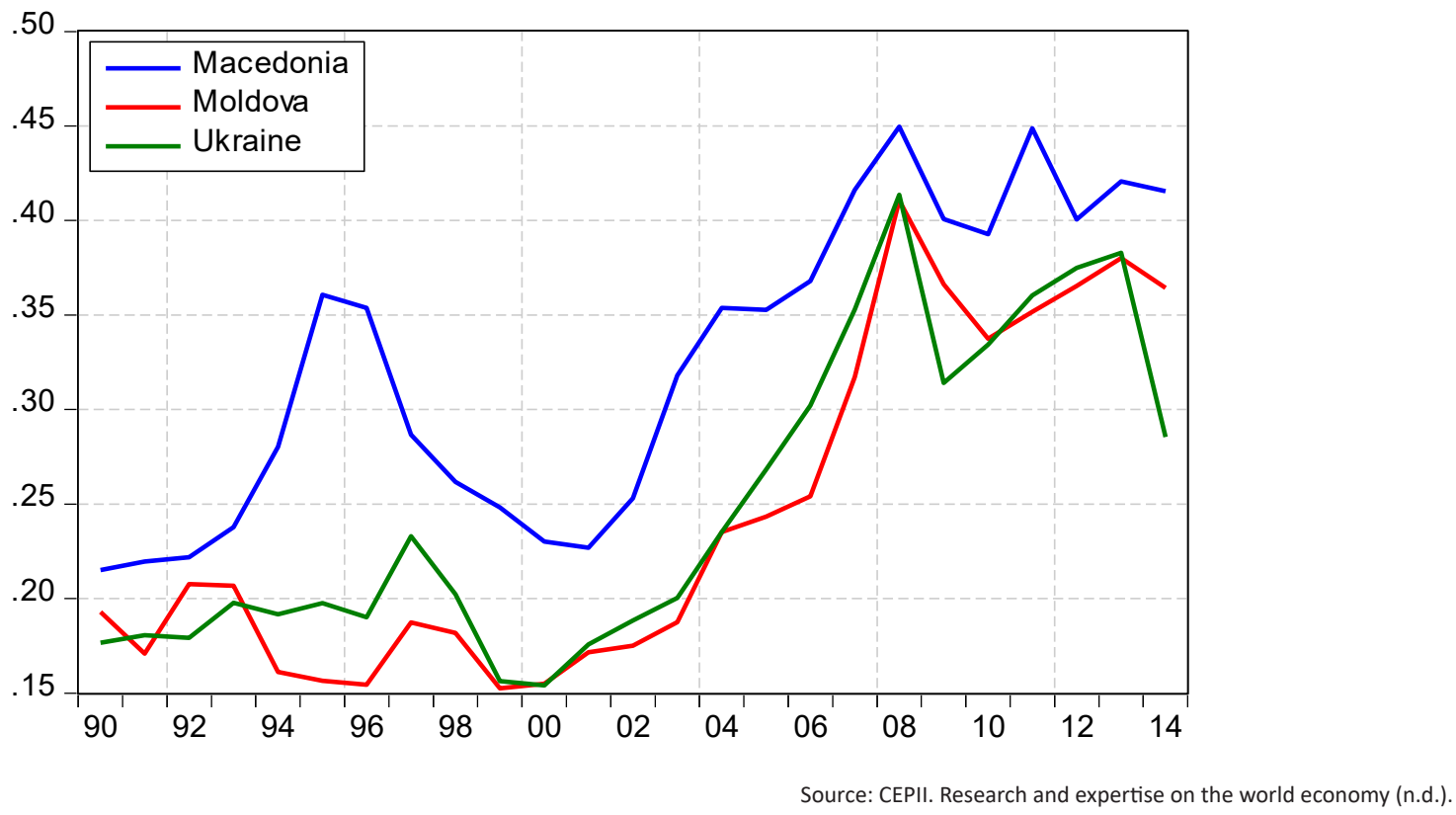

Figure 6. $Q_{t}^{P L}$ for non-EU countries

Table 3. Testing for the Balassa-Samuelson Effect

\begin{tabular}{|c|c|c|c|c|c|}
\hline Modell & $\hat{\beta}_{2}$ & $t\left(\hat{\beta}_{2}\right)$ & $\bar{R}^{2}$ & SIC & $\mathrm{N}$ \\
\hline \multicolumn{6}{|l|}{ All countries } \\
\hline Pooled & $6.79 \cdot 10^{-6}$ & 13.34 & 0.018 & 2.427 & 9.439 \\
\hline $\mathrm{FE}$ & $1.05 \cdot 10^{-5}$ & 11.43 & 0.096 & 2.500 & 9.439 \\
\hline$R E$ & $8.66 \cdot 10^{-6}$ & 11.52 & 0.013 & - & 9.439 \\
\hline \multicolumn{6}{|c|}{ East European Countries } \\
\hline Pooled & $1.89 \cdot 10^{-5}$ & 12.99 & 0.261 & -0.364 & 475 \\
\hline FE & $2.82 \cdot 10^{-5}$ & 13.55 & 0.457 & -0.473 & 475 \\
\hline RE & $2.58 \cdot 10^{-5}$ & 13.57 & 0.276 & - & 475 \\
\hline
\end{tabular}


If the sample is restricted to the 19 East European countries listened above and the period starting in 1990, the sample size reduces to 475 . The slope coefficient is highly significant positive and more than doubles compared to the full sample. In other words, the Penn effect is still intact: the poorer a country, the lower is its price level. The Penn effect can explain more than a quarter of the variability of the real exchange rate in this sub-sample.

\section{CONCLUSION}

To briefly summarize our main results it is very important to admit that the results of current research had underlined that such assumptions as low productivity growth in the non-tradable sector, the law of one price in traded goods, labor mobility, convergence between bordering countries may provide conflicting evidence while estimating the Balassa-Samuelson effect. Identifying a Balassa-Samuelson effect relying on proxies of productivity in the tradable and the non-tradable sectors may thus crucially depend on the choice of a particular monetary policy for the particular country while its currency's exchange rate may fluctuate. This can be the reason why in most East European countries the systematic real appreciation of their currencies came to an end when the International Financial Crisis erupted or shorter after. Secondly, REERs should be supplemented by real exchange rates based on absolute price levels to gauge the level of price competitiveness in addition to its trajectory over time. Thirdly, the Penn effect which states that overvaluation is a positive function of the level of development is still intact and also valid for the sub-sample of East European countries. Unlike previous studies for other European countries, Ukraine is in a lack of the theoretical and empirical testing of the Balassa-Samuelson effect and current research can become a starting point for further studying.

\section{AUTHORS CONTRIBUTIONS}

Conceptualization: Jürgen Kähler.

Data curation: Rosario Cervantes.

Formal Analysis: Jürgen Kähler.

Investigation: Nadiia Proskurnina.

Methodology: Jürgen Kähler.

Project administration: Jürgen Kähler.

Resources: Nadiia Proskurnina, Rosario Cervantes.

Software: Rosario Cervantes.

Supervision: Nadiia Proskurnina.

Validation: Rosario Cervantes.

Visualization: Jürgen Kähler.

Writing - original draft: Jürgen Kähler.

Writing - review \& editing: Nadiia Proskurnina.

\section{REFERENCES}

1. Arratibel, O., Rodriguez-Palenzuela, R., \& Thimann, C. (2002). Inflation Dynamics and Dual Inflation in Accession Countries: A "New Keynesian Perspective" (Working Paper No. 132). Retrieved from https://www.econstor.eu/bitstream/10419/152566/1/ecbwp0132.pdf

2. Asea, P., \& Corden, W. (1994). The Balassa-Samuelson Model: An Overview. Review of International Economics, 2(3), 191-200. https://doi. org/10.1111/j.1467-9396.1994.tb00040.x

3. Asea, P., \& Mendoza, E. (1994). The Balassa-Samuelson Model: A General-Equilibrium Appraisal. Review of International Economics, 2, 244-267. https://www.sas.upenn.edu/ egme/pp/RIE1994.pdf

4. Balassa, B. (1964). The Purchasing Power Parity Doctrine: A Reappraisal. Journal of Political Economy, 72(6), 584-596. Retrieved from https://www.jstor.org/stable/1829464?seq=1

5. Blaszkiewicz, M., Kowalski, P., Rawdanowicz, L., \& Wozniak, P. (2004). Harrod-Balassa-Samuelson Effect in Selected Countries of Central and Eastern Europe (CASE Reports No. 57) (96 p.). Retrieved from https://www.files.ethz.ch/isn/140878/57revised.pdf

6. Candelon, B., Kool, C., Raabe, K., \& Veen, T. (2007). Long-Run Real Exchange Rate Determinants: Evidence from Eight New EU Member States, 1993-2003. Journal of Comparative Economics, 35(1), 87-107. https://doi.org/10.1016/j.jce.2006.10.003 
7. Cassel, G. (1918). Abnormal Deviations in International Exchanges. The Economic Journal, 28(112), 413-415. https://doi. org $/ 10.2307 / 2223329$

8. CEPII. Research and expertise on the world economy (n.d.). Official web-site. Retrieved from http://www.cepii.fr/CEPII/en/welcome.asp

9. Chinn, M. (2006). A Primer on Real Effective Exchange Rates: Determinants, Overvaluation, Trade Flows and Competitive Devaluation. Open Economy Review, 17(1), 115-143. https://doi.org/10.1007/s11079-006-5215-0

10. Clarida, R., \& Gali, J. (1994). Sources of Real Exchange-Rate Fluctuations: How Important Are Nominal Shocks? Carnegie-Rochester Conference Series on Public Policy, 41, 1-56. https://doi.org/10.1016/0167-2231(94)00012-3

11. De Gregorio, J., Giovannini, A., \& Wolf, H. (1994). International Evidence on Tradables and Nontradables Inflation. European Economic Review, 38(6), 1225-1224. https://doi.org/10.1016/0014-2921(94)90070-1

12. Dedu, V., \& Dumitrescu, B. (2010). The Balassa-Samuelson Effect in Romania. Romanian Journal of Economic Forecasting, 10(4), 44-53. Retrieved from http://www.ipe.ro/rjef/rjef4_10/rjef4_10_4.pdf

13. Dornbusch, R. (1987). Purchasing Power Parity (NBER Working Papers No. 1591). Retrieved from https://econpapers.repec.org/paper/ nbrnberwo/1591.htm

14. Dumitru, I. (2008). Efectul Balassa-Samuelson in Romania. Romania in Uniunea Europeana, 36, 11-46. Retrieved from https://mpra. ub.uni-muenchen.de/18611

15. Dumitru, I., \& Ionela, J. (2009). The Balassa-Samuelson effect in Romania - The role of Regulated Prices. European Journal of Operational Research, 194(3), 873-887. https://doi.org/10.1016/j.ejor.2007.12.026

16. Egert, B. (2002a). Investigating the Balassa-Samuelson Hypothesis in the Transition: Do We Understand What We See? A panel study. Economics of Transition becomes Economics of Transition and Institutional Change, 10(2), 273-309. http://dx.doi.org/10.1111/14680351.00112

17. Egert, B. (2002b). Estimating the Impact of the Balassa-Samuelson Effect on Inflation and the Real Exchnage Rate during the Transition. Economic Systems 26(1), 1-16. https://doi.org/10.1016/S0939-3625(02)00002-X

18. Egert, B. (2004). Equilibrium exchange rates in South Eastern Europe, Russia, Ukraine and Turkey: Healthy or (Dutch) diseased? Economic Systems, 29(2), 205-241. https://doi.org/10.1016/j.ecosys.2005.03.008

19. Egert, B. (2005). Balassa-Samuelson Meets South Eastern Europe, the CIS and Turkey: A Close Encounter of the Third Kind? The European Journal of Comparative Economics, 2(2), 221-243. Retrieved from http://ejce.liuc.it/Default.asp?tipo=articles\&identifier=ej ce:18242979/2005/02/04

20. Egert, B. et al. (2003). The Balassa-Samuelson Effect in Central and Eastern Europe: Myth or Reality? Journal of Comparative Economics, 31(3), 552- 572. https://doi.org/10.1016/S0147-5967(03)00051-9

21. Feenstra, R., Inklaar, R., \& Timmer, M. (2015). The Next Generation of the Penn World Table. American Economic Review, 105(10), 31503182. Retrieved from https://www.aeaweb.org/articles?id=10.1257/aer.20130954

22. Flood, R., \& Taylor, P. (1996). Exchange Rate Economics: What's Wrongwith the Conventional Macro Approach? In The Microstructure of Foreign Exchange Markets (pp. 261-302). Chicago: Chicago University Press. Retrieved from https://econpapers.repec.org/bookchap/ nbrnberch/11368.htm

23. Froot, K., \& Rogoff, K. (1994). Perspectives on PPP and Long-Run Real Exchange Rates. In G. Grossman, K. Rogoff (Ed.), Handbook of international Economics, 3 (pp. 1647-1688). https://doi.org/10.3386/w4952

24. Giovannini, A. (1998). Exchange rates and Traded Goods Prices. Journal of International Economics, 24(1/2), 45-68. https://doi. org/10.1016/0022-1996(88)90021-9

25. Halpern, L., \& Wyplosz, C. (2001). Economic Transformation and Real Exchange Rates in the 2000s: The Balassa-Samuelson Connection. Economic Survey of Europe, 1(1), 227-239. Retrieved from http://www.unece.org/fileadmin/DAM/ead/pub/011/011_c6.pdf

26. Hsieh, D. (1982). The Determination of the Real Exchange Rate. The Productivity Approach. Journal of International Economics, 12(3-4), 355-362. https://doi.org/10.1016/0022-1996(82)90045-9

27. Isard, P. (1977). How Far Can We Push the "Law of One Price"? The American Economic Association, 67(5), 942-948. Retrieved from https://www.jstor.org/stable/1828075?seq=1

28. Marston, R. (1987). Real Exchange Rates and Productivity growth in the United States and Japan. In S. Arndtand, J. Richardson (Ed.), Journal Real Financial Linkages among Open Economies (pp. 71-96). Cambridge: MIT Press. Retrieved from https://www.nber.org/papers/ w1922

29. Mihaljek, D., \& Klau, M. (2004). The Balassa-Samuelson Effect in Central Europe: A Disaggregated Analysis. Comparative Economic Studies, 46(1), 63-94. https://doi.org/10.1057/palgrave.ces.8100041

30. O'Connell, P., \& Wie, S. (1997). The Bigger They Are, The Harder They Fall: How Price Differences Across U.S. Cities Are Arbitraged (NBER Working Papers 6089) (33 p.). National Bureau of Economic Research, Inc. https://doi.org/10.3386/w6089

31. Parsley, D., \& Wie, S. (1996). Convergence to the Law of One Price Without Trade Barriers or Currency Fluctuations. The Quarterly Journal of Economics, 111(4), 1211-1236. Retrieved from https://www.jstor.org/stable/2946713?seq=1

32. Rogoff, K. (1996). The Purchasing Power Parity Puzzle. Journal of Economic Literature, 34(2), 647-668.

33. Samuelson, P. (1964). Theoretical Notes on Trade Problems. The Review of Economics and Statistics, 46(2), 145-154. Retrieved from https:// www.jstor.org/stable/1928178?seq=1

34. Sarno, L., \& Chowdhury, I. (2001). Nonlinear Dynamics in Deviations from the Law of One Price: A Broad-Based Empirical Study. Journal of Money, Credit, and Banking. http://dx.doi.org/10.2307/2946713

35. Sarno, L., \& Taylor, A. (2002). Purchasing Power Parity and the Real Exchange Rate. IMF Staff Papers, 49(1), 65-105. Retrieved from https://www.imf.org/External/Pubs/FT/staffp/2002/01/pdf/sarno.pdf

36. Taylor, A. (2002). A Century of Purchasing-Power Parity. The Review of Economics and Statistics 84(1), 139-150. https://doi. org/10.1162/003465302317331973 